\title{
Evaluation of Secchi Depth in a Shallow Alpine Lake by Principal Component Analysis
}

\author{
Kumiko YaJIMA
}

\begin{abstract}
Principal component analysis (PCA) was applied to evaluate some of the potential factors contributing to Secchi depth (SD) in the oligotrophic alpine Lake Oze-Numa, using seven water quality parameters obtained during 1990-1992. The data on SD, water temperature (WT), chemical oxygen demand (COD), total nitrogen (TN), suspended solids (SS), total phosphorus (TP), and chlorophyl- $a$ (CHL) were examined. The first component had large loadings on SD, WT, SS, TP, and CHL attributable to phytoplankton population. COD and TN correlated with the second component, showing natural contributions. SD was revealed to be a reliable indicator of eutrophication in the lake, as it was predicted successfully by multiple linear regression analysis using SS, TP, and CHL as independent variables. A time-series analysis of the SD records was applied to a simple estimation of the eutrophication rate of the lake. $\mathrm{SD}$ has decreased for the past 25 years $(1965-1990)$ at a rate of $0.065 \mathrm{~m} \cdot \mathrm{yr}^{-1}$ or $1.2 \%$. $\mathrm{yr}^{-1}$. The SD trend was partly explained by the increase in TP concentration attributable to tourists.
\end{abstract}

Key words : alpine lake, eutrophication, principal component analysis, Secchi depth

\section{Introduction}

Most alpine lakes need to be preserved as components of an important natural heritage for future generations. Time-series analysis in such a lake often gives useful information toward taking measures for preservation. Secchi depth (SD) is an important parameter for trend analysis, because, being different from many chemical parameters, SD data in many lakes have been recorded using simple observation methods since the 19th century (HuTchin. SON, 1957).

In oligotrophic lakes without anthropogenic pollution, changes in SD would generally be difficult to recognize, because the pace of natural eutrophication would be slow compared with changes due to human generation. For example, SD in Lake Tahoe has not suffered any marked decline for almost 90 years from 1873 to 1962 (GoldMAN and CARTER, 1965). For that reason, little time-trend analysis of $\mathrm{SD}$ seems to have been conducted in oligotrophic alpine lakes, in contrast with many studies in eutrophic lakes in urbanized areas (HASLER, 1947 ; DAvIS, 1964).

Concerning its validity as an index of eutrophication, SD is generally regarded as a good parameter of phytoplankton population in many lakes where SD closely correlated with the concentration of total phosphorus or chlorophyl- $a$ (CARLSON, 1977; OECD, 1982). However, many factors other than phytoplankton, such as inorganic suspended solids and dissolved humic substances, are often recog. nized as contributing greatly to SD (LORENZEN, 1980; MEGARD et al., 1980).

Considering the complexity of SD, some method of multivariate analysis, such as principal component analysis (PCA), can be important in revealing potential factors affecting SD ; information available for lake management in individual lakes. PCA analysis has been used successfully for examining water quality (Hoshino et al., 1984), atmospheric environment (PRATSINIS et al., 1988), and lake sediment 
(FUKUSHima et al., 1991). Yoshimi et al. (1982) used an integrated Water Quality Index calculated by PCA to evaluate the pollution from human activities in the Sagami River. However, PCA has not yet been applied to the evaluation of SD in a lake. The objectives of this study are (i) to evaluate by PCA some of the potential factors contributing to $\mathrm{SD}$, using the data of water quality in a shallow alpine lake, and (ii) to apply the long-term changes in SD to estimate the eutrophication rate of the lake from 1965 to 1990.

\section{Materials and methods}

\section{2-1. Site description}

Lake Oze-Numa $\left(36^{\circ} 56^{\prime} \mathrm{N}, 139^{\circ} 18^{\prime} \mathrm{E}\right)$, one of the most famous alpine lakes in Japan, is situated $1662 \mathrm{~m}$ above sea level. The lake has $1.84 \mathrm{~km}^{2}$ of surface area, a maximum depth of $9.5 \mathrm{~m}$, lake volume of $10.75 \times 10^{6} \mathrm{~m}^{3}$, a catchment area of $13.1 \mathrm{~km}^{2}$ including the lake surface, and an average hydraulic residence time of 0.58 year (calculated by the author from hydraulic data compiled by the Gunma Prefectural Government, 1983-1991). The natural environment in the district has been protected as a Special Natural Treasure in Japan since 1960 because of its scientific significance and pristine character. Recently, however, there has been much concern about the eutrophication of the lake from tourism. The wastewater from hotels on the eastern side, has flowed into the lake after inadequate treatment for more than three decades, except for six months every winter when the hotels are closed due to heavy snowfall. The number of tourists in the district is estimated to be more than 500 thousand a year with the rate rapidly increasing since the 1970s.

\section{2-2. Lake survey and analytical methods}

Water samples were collected eighteen times during 1990-1992 (monthly from May to October), vertically at $0 \mathrm{~m}$ and $3 \mathrm{~m}$ depths in the center of the lake. Water temperature (WT, $\left.{ }^{\circ} \mathrm{C}\right)$ and $\mathrm{SD}(\mathrm{m})$ were measured at the time of sampling. A white Secchi disk $30 \mathrm{~cm}$ in diameter was used for SD measurement. Water samples collected in plastic bottles were transported in a cooler box filled with ice to the laboratory and analyzed immediately on arrival. Chemical oxygen demand (COD, mg • $1^{-1}$ ) was determined by the back titrimetric method after oxidation by potassium permanganate at $100^{\circ} \mathrm{C}$ for $30 \mathrm{~min}$. Suspended solids (SS, $\mathrm{mg} \cdot \mathrm{l}^{-1}$ ) were determined by filtration on a Whatman GF/C glass-fiber filter. Total nitrogen ( $\mathrm{TN}, \mathrm{mg} \cdot \mathrm{l}^{-1}$ ) was calculated by a heat decomposition-chemiluminescence detection system using a total nitrogen analyzer (Yanako $\mathrm{TN}-7$ ). These three parameters were analyzed according to the Japanese industrial standard method (JISC, 1936). Total phosphorus (TP, $\mathrm{mg} \cdot \mathrm{1}^{-1}$ ) was determined by spectrophotometry after extracting phosphomolybdic acid complex with butyl acetate (ISHIBASHI and TABUSHI, 1959). Chlorophyl-a (CHL, $\left.\mathrm{mg} \cdot \mathrm{m}^{-3}\right)$ was quantified by the fluorometric method after the extraction of particulate matter collected on a Whatman GF/C filter with $90 \%$ acetone (APHA, 1989).

\section{2-3. Statistical analysis}

The arithmetic means for six parameters except $\mathrm{SD}$ at $0 \mathrm{~m}$ and $3 \mathrm{~m}$ depths were calculated for each month. A program package, NAP (AOKI, 1989), was used for the PCA calculation. Each parameter was checked for normal distribution. Root-transformation was needed for CHL and natural log transformation for SD, COD, SS, TN and TP, but no transformation was needed for WT.

\section{2-4. Data base of SD and TP}

Historical SD data of for time-series analysis were compiled from the monitoring reports for May-October 1976-1990 (Gunma Prefectural Government, 1976-1990), and the relevant literature (JAPAN ENVIRONMENTAL AGENCY, 1972 ; KURITA et al., 1973). TP concentration for analysis of recent trends was also compiled from the monitoring data at depths of $0 \mathrm{~m}, 3 \mathrm{~m}$ and $6 \mathrm{~m}$ during May-October (GUNMA PREFEC. TURAL GOVERNMENT, 1982-1990) 


\section{Results and discussion}

\section{3-1. Principal component analysis}

Arithmetic means and standard deviations for all data during 1990-1992 were shown in Table 1. TN, TP, and CHL data in the Table indicated that the trophic state of the lake was on the boundary of oligo- and mesotrophy (OECD, 1982). SD correlated negatively with SS, TP and CHL, and positively with WT with the significant level at $P<0.01$ (Table 2). TN correlated moderately only with COD $(P<$ 0.05). PCA revealed two principal components, comprising $74.6 \%$ of the total variance (Table 3). The first component accounted for $50.8 \%$ of the variance and showed positive factor loadings in SD and WT, and negative ones in SS, TP and CHL. The second component had high loadings in COD and TN, accounting for $23.9 \%$

Table 1. Arithmetic means and standard deviations of seven water quality parameters in Lake Oze-Numa, 1990 $-1992$.

\begin{tabular}{lrrc}
\hline \multicolumn{2}{c}{ Parameters } & $n$ & Mean $\pm \mathrm{SD}$ \\
\hline $\mathrm{SD}$ & $(\mathrm{m})$ & 18 & $3.7 \pm 1.01$ \\
$\mathrm{WT}$ & $\left({ }^{\circ} \mathrm{C}\right)$ & 36 & $16.9 \pm 4.38$ \\
$\mathrm{COD}$ & $\left(\mathrm{mg} \cdot \mathrm{l}^{-1}\right)$ & 36 & $2.9 \pm 0.31$ \\
$\mathrm{SS}$ & $\left(\mathrm{mg} \cdot \mathrm{l}^{-1}\right)$ & 36 & $2.4 \pm 1.03$ \\
$\mathrm{TN}$ & $\left(\mathrm{mg} \cdot \mathrm{l}^{-1}\right)$ & 36 & $0.18 \pm 0.055$ \\
TP & $\left(\mathrm{mg} \cdot \mathrm{l}^{-1}\right)$ & 36 & $0.012 \pm 0.0032$ \\
$\mathrm{CHL}$ & $\left(\mathrm{mg} \cdot \mathrm{l}^{-3}\right)$ & 36 & $2.8 \pm 1.94$
\end{tabular}

Abbreviations: SD (Secchi depth), WT (water temperature), COD (chemical oxygen demand), SS (suspended solids), TN (total nitrogen), TP (total phosphorus), CHL (chlorophyl a). of the variance.

The first and second factor loadings of seven parameters were plotted to determine similarities among the parameters (Fig. 1). The parameters seemed classifiable into three groups based on the proximity of the coordinates in Figure 1. Group 1 consisted of physical parameters: WT and SD, Group 2 contained chemical parameters: SS, TP and CHL. Group 3 consisted of COD and TN. Group 1 had a negative correlation with Group 2 since both groups were plotted roughly on a symmetrical position to the origin of the coordinates. Group 3 was plotted independently of the other two. COD and TN loads from natural origins, such as stream and rain waters, contributed greatly to the water quality in this oligo-mesotrophic lake (YAJIMA et al., 1986), even though both parameters are generally regarded as reliable indicators of phytoplankton abundance in many eutrophic lakes (OECD, 1982 ; FuKUSHIMA and MuraOKA, 1988). Consequently, the first axis (F1) could be attributable to the extent of phytoplankton abundance, and the second axis (F2) primarily to the level of COD and TN originating from natural sources.

The factor scores of the first component in each sample in 1990-1992 were shown in Figure 2 to determine seasonal variations in the parameters primarily for Groups 1 and 2. The negative scores implied a high phytoplankton population associated with the higher values of Group 1 and the lower concentrations of Group 2 , as compared to the positive values in Figure 2. Those positive values tended to be found in

Table 2. Pearson's moment correlation coefficients between seven water quality parameters in Lake Oze-Numa, 1990-1992.

\begin{tabular}{llllllll}
\hline & $\mathrm{SD}$ & $\mathrm{WT}$ & $\mathrm{COD}$ & $\mathrm{SS}$ & $\mathrm{TN}$ & $\mathrm{TP}$ & $\mathrm{CHL}$ \\
\hline $\mathrm{SD}$ & 1.000 & & & & & & \\
$\mathrm{WT}$ & $0.682^{* *}$ & 1.000 & & & & & \\
$\mathrm{COD}$ & $-0.476^{*}$ & -0.211 & 1.000 & & & & \\
$\mathrm{SS}$ & $-0.727^{* *}$ & $-0.774^{* *}$ & 0.068 & 1.000 & & & \\
TN & -0.253 & -0.398 & $0.505^{*}$ & 0.159 & 1.000 & & \\
TP & $-0.723^{* *}$ & -0.403 & 0.417 & $0.646^{* *}$ & 0.132 & 1.000 & \\
CHL & $-0.683^{* *}$ & $-0.708^{* *}$ & 0.308 & $0.661^{* *}$ & 0.330 & $0.584^{*}$ & 1.000 \\
\hline
\end{tabular}

* or **: statistically significant at $P<0.05$ or 0.01 , respectively. Abbreviations refer to Table 1. 
June, July and August, and the negative ones in May, September and October, with slight variations from year to year. The regular seasonal trend in Figure 2 may be attributed in part to phytoplankton abundance.

In order to evaluate the validity of SD as an index of integrated water quality correlated with phytoplankton, the relationships between observed and predicted SD were compared. Stepwise multiple linear regression analysis was performed for the prediction of $\mathrm{SD}$, in which the analysis dependent variable was SD and the independent ones were TP, CHL and SS (Group 2). As a result of the analysis, SD was

Table 3. Factor loadings of first and second components after Varimax rotation by principal component analysis.

\begin{tabular}{lrrr}
\hline & Factor 1 & Factor 2 & $\begin{array}{c}\text { Cumulative } \\
\text { contribution* }\end{array}$ \\
\hline SD & 0.852 & -0.295 & 0.813 \\
WT & 0.821 & -0.187 & 0.709 \\
COD & -0.173 & 0.874 & 0.793 \\
SS & -0.934 & -0.074 & 0.878 \\
TN & -0.141 & 0.823 & 0.697 \\
TP & -0.752 & 0.205 & 0.608 \\
CHL & -0.816 & 0.245 & 0.726 \\
\hline Eigenvalue & 3.55 & 1.67 & \\
Contribution \% & 50.78 & 23.87 & \\
\hline
\end{tabular}

* : cumulative contribution of first and second components to original variable. Abbreviations refer to Table 1.

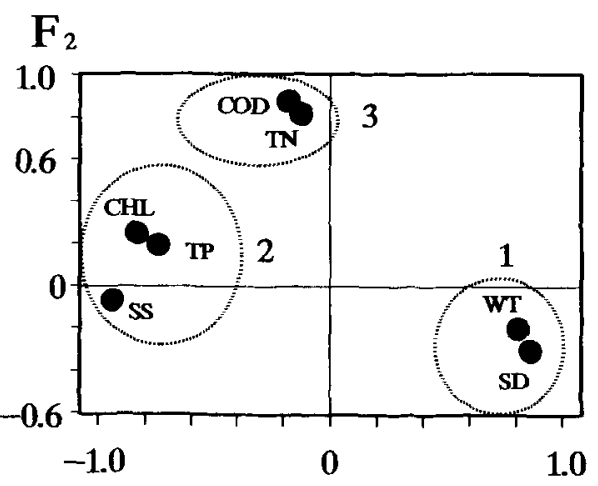

\section{Factor loadings of $F_{1}$}

Fig. 1. Relationship between factor loadings of the first and second components of the seven parameters in PCA. approximately predicted by the following equation $\left(n=18, r^{2}=0.674, P<0.005\right)$ :

$\operatorname{lnSD}=-0.167-0.229 \operatorname{lnSS}-0.410 \operatorname{InTP}$ $-0.1340 \sqrt{\mathrm{CHL}}$ (eq. 1) where the units of parameter measurement were meters in $\mathrm{SD}$, $\mathrm{mg} \cdot \mathrm{1}^{-1}$ in SS and TP, and $\mathrm{mg} \cdot \mathrm{m}^{-3}$ in CHL. SD in the lake was regarded as a valid eutrophication index predicted by TP, SS and CHL, because a linear relationship was found between both SDs (Fig. 3, $n=18, r=0.821, P<0.001$ ).

\section{3-2. Long-term change in SD for $1965^{-}$ 1990}

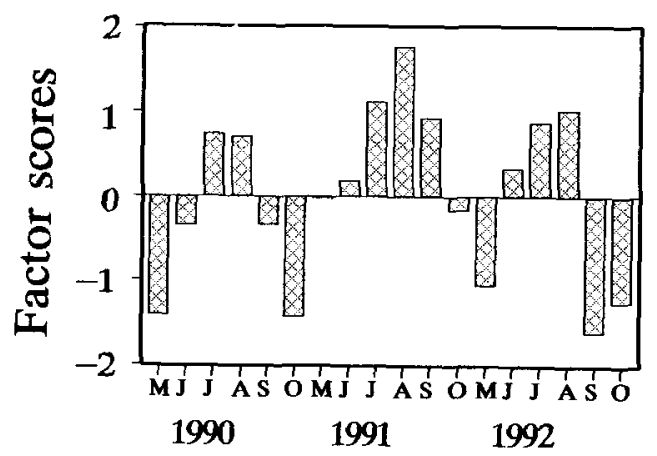

Fig. 2. Seasonal variations in factor scores of the first component in PCA. PCA was performed on samples during May-October, 1990 -1992 , using seven parameters: WT, SD, SS, TP , COD, TN and CHL.

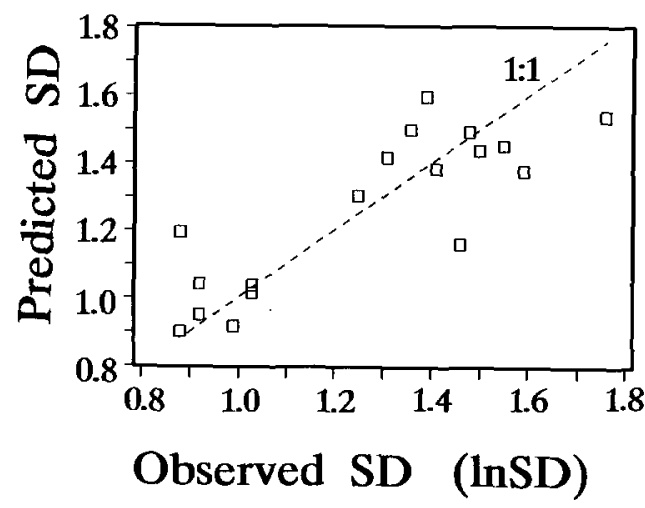

Fig. 3. Relationship between observed and predicted SD, 1982-1990. Predicted SD was calculated by multiple linear regression analysis using SS, TP and CHL as independent variables (eq.1). A broken line denotes $1: 1$ line of observed SD transformed to natural logarithm. 
Long-term SD in Lake Oze-Numa for 19651990 was found to be decreasing rapidly at a rate of $0.065 \mathrm{~m} \cdot \mathrm{yr}^{-1}$ (or $1.2 \% \cdot \mathrm{yr}^{-1}$ based on the earliest value of $5.37 \mathrm{~m}$ in 1965), in spite of large seasonal variations. The regression line was:

$$
\mathrm{SD}=-0.065 \mathrm{Y}+9.33
$$

(eq. 2, $n=142, r=-0.34, P<0.001$ ),

where $\mathrm{Y}$ was the year since 1 January 1900 . To get more precise information about the SD trend, it was analyzed separately, taking into account the thermal properties of the lake. Summer stratification usually formed from mid-June to August and most strongly in July, while the autumn overturn began in late August

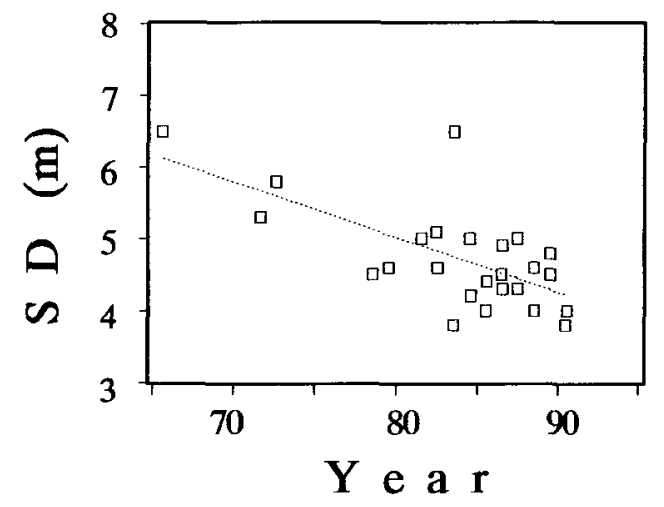

Fig. 4. Long-term SD in summer stagnation period, 1965-1990. Regression line is: $\mathrm{SD}=-0.077 \mathrm{Y}+11.16 \quad(n=26, r=-0.66$, $P<0.001$ ), where $\mathrm{Y}$ is years starting from 1 January 1900 .

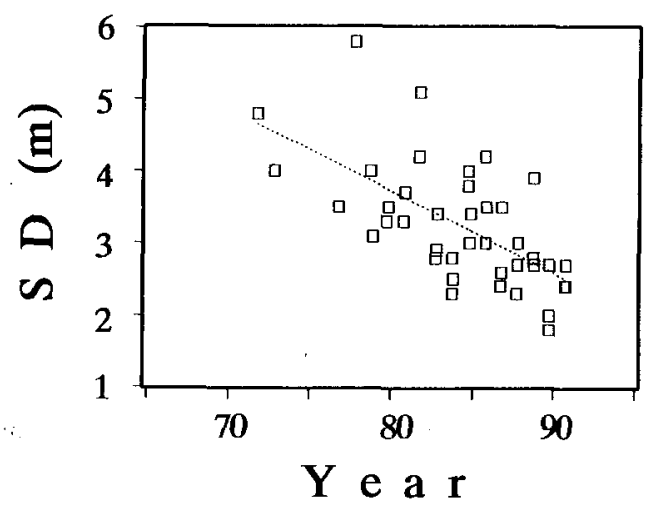

Fig. 5. Long-term SD in autumn overturn period, 1971-1990. Regression line is: $\mathrm{SD}=-0.113$ $\mathrm{Y}+12.80 \quad(n=40, \quad r=-0.64, \quad P<0.001)$, where $\mathrm{Y}$ is same as Fig 4. and was completed in late September-October (SUGAWA, 1992).

Both trends for SD in July (Fig. 4) and in late September and October (Fig. 5) were declining, though indicating a steeper slope of regression line in Figure 5 than that in Figure 4. According to seasonal variations in the factor scores in Figure 2, those in autumn tended to be lower than those in summer, supposing lower values for SD and more abundant phytoplankton population in the former season. The biomass of diatoms in the lake was richer in May and autumn when water temperatures were lower than in the summer months (NAKAJIMA and KoBE, 1986). The trend of SD in autumn (Fig. 5) may be attributed in part to the increase in diatoms caused by TP transported from the bottom water in the autumn overturn period as inferred from the relationship among $\mathrm{SD}, \mathrm{TP}$, SS and CHL in eq. 1.

The decreasing trend of SD in summer (Fig. 4) may be also caused by the long-term increase in phytoplankton and TP. However, it is not clear at present why the decreasing trend of SD in Figure 5 is larger than in Figure 4. One of the distinguishing factors affecting $\mathrm{SD}$ between autumn and summer would be an ecological one, such as the interrelationship between phytoplankton and other aquatic organisms: zooplankton, zoobenthos, and aquatic macrophytes (OHMori and Ikushima, 1988 ; Hanazato and NOHARA, 1992). More precise ecological research will be necessary to clarify the factors affecting SD, especially in summer.

Consequently, the long-term decrease in SD in eq. 2 is interpreted to be one of the eutrophication symptoms arising from tourism, since human activity has been limited strictly to tourism. Furthermore, no natural disaster that could cause an SD decrease has occurred in this area since 1965. It would be useful to evaluate the decreasing rate of SD as a simple index for the eutrophication rate in the lake.

\section{3-3. Relationship between in-lake and external TP}

To elucidate the cause of the long-term decrease in $\mathrm{SD}$, the trend of annual mean in-lake 
TP concentration ( $\left.[\mathrm{TP}], \mathrm{mg} \cdot \mathrm{m}^{-3}\right)$ was examined. [TP] was calculated from the data of the vertical mean TP concentrations at depths of 0,3 and $6 \mathrm{~m}$ during May-October 1982 -1990. [TP] showed a linear increase from 7.5 $\mathrm{mg} \cdot \mathrm{m}^{-3}$ in 1982 to $14.4 \mathrm{mg} \cdot \mathrm{m}^{-3}$ in 1990 at a rate of $0.867 \mathrm{mg} \cdot \mathrm{m}^{-3} \cdot \mathrm{yr}^{-1}$ (or $11.6 \% \cdot \mathrm{yr}^{-1}$ based on the $[T P]$ in 1982). The regression line was:

$$
[\mathrm{TP}]=0.867 \mathrm{Yr}-1711
$$$$
\text { (eq. } 3, n=9, r=0.886, P<0.001 \text { ) }
$$

where $\mathrm{Yr}$ was the calendar year. Although the $\mathrm{TP}$ concentration in the lake itself was not necessarily high compared with the oligotrophic pool water in Ozegahara moor, which is well protected from the effects of human activities and shows TP concentrations of 2.6-11.5 mg • $\mathrm{m}^{-3}$ (SAKAMOTO, 1982), the rate of increase in the lake was so high as to lead eq. 3 to a prediction of a mesotrophic condition of 23.1 $\mathrm{mg} \cdot \mathrm{m}^{-3}$ by the year 2000 .

External TP loads were examined for human inputs based on the TP contents of the meals at the hotels as well as for natural TP concentrations analyzed in stream, rain and snow water samples collected around the lake in 1979 (UJIYY et al., 1981). As a result, the TP load of human origin was estimated to be $69 \%$ of the sum of human and natural inputs. And $37 \%$ of total TP loads was calculated to remain in the sediment by the mass balance method.

The annual mean external TP load for 19821990 was estimated at $196.5 \mathrm{~kg} \cdot \mathrm{yr}^{-1}$, of which $137.9 \mathrm{~kg} \cdot \mathrm{yr}^{-1}$ was of human origin and the remaining $58.6 \mathrm{~kg} \cdot \mathrm{yr}^{-1}$ from natural causes. This estimate was based on the same calculation as in 1979 using the annual number of tourists and the amounts of annual precipitation and inflowing hydraulic load during 1982-1990. The annual mean specific surface load of TP $\left(\mathrm{mg} \cdot \mathrm{m}^{-2} \cdot \mathrm{yr}^{-1}\right.$ ) over that period was calculated to be $107 \mathrm{mg} \cdot \mathrm{m}^{-2} \cdot \mathrm{yr}^{-1}$, which was equal to the annual mean external TP load (196.5 $\left.\mathrm{kg} \cdot \mathrm{yr}^{-1}\right)$ divided by the lake surface area (OECD, 1982). The load was not so much larger than that for representative oligotrophic deep lakes such as Lake Tahoe or Lake Superior $\left(30-40 \mathrm{mg} \cdot \mathrm{m}^{-2}\right.$. $\mathrm{yr}^{-1}$ ), and was similar to that for oligomesotrophic deep lakes such as Lake Michigan or Lake Huron (130-140 $\mathrm{mg} \cdot \mathrm{m}^{-2} \cdot \mathrm{yr}^{-1}$ ) (VOL LENWEIDER, 1976 ). On the other hand, the TP load in the north basin of Lake Biwa was about $800 \mathrm{mg} \cdot \mathrm{m}^{-2} \cdot \mathrm{yr}^{-1}$ (KUNIMATSU and KITAMURA, 1981). In that basin (mean depth, $45.5 \mathrm{~m}$ ), annual mean SD and TP concentrations did not show any decrease / increase during 1966-1989. Almost all external phosphorus seemed to be transported to the bottom by sedimentation without recycling during the circulation period (TEZuKA, 1992). However, in the case of shallow Lake Oze-Numa, TP transported to the bottom sediment may be recycled more easily in autumn than is the case in Lake Biwa. One simple method for detecting the transportation of $\mathrm{TP}$ in the sediment water would be to compare observed TP concentrations with calculated annual mean inflowing ones, the latter being equal to the annual external TP load divided by the annual hydraulic load (OECD, 1982). Inflowing TP concentrations showed close agreement with those observed during 1982-1990 (Fig. 6, $n=9, \quad r=0.817$, $P<0.001)$. Judging from the results in Figure 6, phosphorus accumulated in the bottom sediments over many tourist seasons may have been

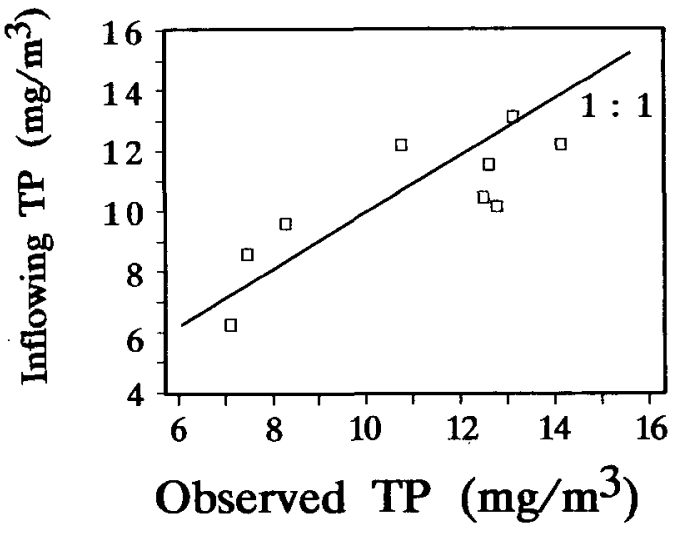

Fig. 6. Relationship between observed and calculated inflowing TP concentrations, 19821990. Observed TP is annual mean TP concentration measured at 0,3 , and $6 \mathrm{~m}$ during May-October, 1982-1990. Calculated TP denotes annual mean inflowing TP concentration. Annual external TP load was divided by annual hydraulic load to get calculated TP. A solid line denotes 1:1 line of observed TP concentrations. 
transported to the lake water, especially in the years of under-deviations from the $1: 1$ line of observed values. The shallow depth of Lake Oze-Numa seems to play an important role in causing the increasing trends of $\mathrm{TP}$ and the decreasing ones of SD.

The strictest criterion in the environmental water quality standard for $\mathrm{TP}, 5 \mathrm{mg} \cdot \mathrm{m}^{-3}$, determined by the Japan Environmental Agency is equivalent to the TP concentration in 1979 from eq.3. This will be an acceptable value for maintaining Lake Oze-Numa as oligotrophic, taking into account the natural TP concentrations of streams and rain water of 2$5 \mathrm{mg} \cdot \mathrm{m}^{-3}$ in the area (SAKAMoto, 1982 ; YaJima et al., 1983). Consequently, in order to preserve the lake at least in its present trophic condition, the annual TP load from tourism should be reduced to less than $88 \%$ every year based on the increased rate of TP concentration in eq. 3 . This would call for such effective measures as limiting the number of tourists, or reducing the external load from sewage-treatment or sewage-diversion systems.

\section{Acknowledgements}

The author expresses sincere thanks to Professor Shosuke Suzuki of the Gunma University School of Medicine for his advice in the preparation of the manuscript, and to Professor Shigenobu AoKI, Faculty of the Social Information Sciences, Gunma University, for his suggestions on statistical analysis. I am deeply indebted to Dr. Yasuhiko TEzuKA, former Professor of the Center for Ecological Research, Kyoto University, for his valuable advice on the early manuscript. Thanks are also due to Dr. Kunio OHTUKI, Director of the Gunma Prefectural Institute of Public Health and Environmental Sciences for his encouragement, and to the former and current staff members of the Institute for the lake survey. Finally I am grateful to two anonymous reviewers for improvements in the manuscript.

\section{摘 要 \\ 主成分分析を用いた浅い山岳湖沼における セッキ板透明度の評価}

賓栄養山岳湖沼におけるセッキ板透明度の影響 因子を評価するために，尾瀬沼の 1990 年〜1992 年の 7 項目の水質指標；セッキ板透明度・水温・ 化学的酸素要求量 - 懸濁物質・全空素・全燐・ク ロロフィルaを用いて，主成分分析を実施した。 主成分分析における第一主成分の因子負荷量は, セッキ板透明度・水温・懸濁物質・全燐・クロロ フィルaで大きく，植物プランクトン量の因子と 考えられた。化学的酸素要求量・全窒素は第二主 成分との相関が高く,この湖では自然由来の因子 が第一主成分の因子とは異なる挙動を示すことが 示唆された。セッキ板透明度は，懸濁物質・全燐・ クロロフィルaの 3 項目を独立変数とした重回帰 分析によりほぼ予測されることから，透明度はこ の湖の䈏栄養化の指標として信頼できるものと考 えられた。この湖の富栄養化速度を簡便に評価す るために, 透明度の時系列解析を応用した。透明 度は 1965 年 1990 年の 26 年間に, $0.065 \mathrm{~m} \cdot \mathrm{yr}^{-1}$ 又は, $1.2 \% \cdot \mathrm{yr}^{-1}$ の速度で減少していた。透明度 の減少傾向の一因として, 観光客由来の燐の蓄積 による湖水中の全燐濃度の上昇, それによる植物 プランクトン量の増加が洘えられた。

\section{References}

American Public Health Association (1989): Standard Methods for the Examination of Water and Wastewater, 17th edition. APHA., Washington, DC.

AoKI, S. (1989) : NAP Computer System in Reference Manual for Medical Statistics, p. 470. Igakushoin, Tokyo (in Japanese).

CARLSON, R.E. (1977): A trophic state index for lakes. Limnol. Oceanogr., 22 : 361-369.

DAVIS, C.C. (1964) : Evidence for the eutrophication of Lake Erie from phytoplankton records. Limnol. Oceanogr., $9: 275-283$.

FukUshima, T. and K. MuraOKA (1988): Simple model to predict water quality in 90 Japanese lakes. Verh. Internat. Verein. Limnol, 23 : 812827.

Fukushima, T., K. Amano and K. Muraoka (1991): Factors explaining sediment concentrations of 16 elements in 28 Japanese eutrophic lakes. Wat. Sci. Tech., 23:465-474.

Goldman, C.R. and R.C. CARTER (1965) : An investigation by rapid carbon-14 bioassay of factors 
affecting the cultural eutrophication of Lake Tahoe, California-Nevada. JWPCF., 37 : 10441059.

Gunma Prefectural Government (1976-1990) : Annual report of water quality of the public water in Gunma Prefecture (in Japanese).

Gunma Prefectural Government (1983-1991): Annual report for conservation of natural environment in Oze, No. 6-14 (in Japanese).

Hanazato, T. and S. Nohara (1992): Seasonal succession and vertical distribution of zooplankton in Lake Ozenuma. Jpn. J. Limnol., $53: 55$ $-63$.

HASLER, A. D. (1947) : Eutrophication of lakes by domestic drainage. Ecology, 28 : 383-395.

Hoshino, Y., S. Sato, M. Sakai and T. Yoshida (1984): Characterization of water quality of newly constructed reservoir using Principal Component Analysis. Japan. J. Wat. Pollut. Res., 5: 193-200 (In Japanese with English summary).

Hutchinson, G. E. (1957) : A Treatise on Limnology, Vol. I, p. 1015. John Wiley and Sons, New York.

Ishibashi, M. and M. TABushi (1959): Spectrophotometric determination of micro amount of phosphoric acid by solvent extraction as phosphomolybdate. Jap. Analyst, 8: 588-593 (In Japanese with English summary).

JAPAN Environmental AgEnCy (1972): Report of water quality of lakes in National Park : p. 264. Japan Environmental Agency (in Japanese).

JAPANESE Industrial Standards Committee (1986) : Japanese Industrial Standard, Testing Methods for Industrial Wastewater, JIS K 0102. Japanese Standards Association, Tokyo.

Kunimatsu, T. and G. Kitamura (1981): Phosphorus balance of Lake Biwa. Verh. Internat. Verein. Limnol., 21 : 539-544.

Kurita, H., H. Minemura and Y. Miyahara (1973): Limnological research in Lake Oze-Numa, p. 170. In Report of Special Natural Monument Oze. Gunma Prefectural Board of Education (in Japanese).

LORENZEN, M. W. (1980) : Use of chlorophyll-Secchi disk relationships. Limnol. Oceanogr., 25 : 371372 .

Megard. R. O., J. C. Settles, H. A. Boyer and W. S. Combs, Jr. (1980) : Light, Secchi disks, and trophic states. Limnol. Oceanogr., $25: 373-377$.

N.akajima, K. and T. Kobe (1986) : Vertical distribution of diatoms in Lake Oze-Numa. Annual Report of Gunma Institute of Public Health, 18: 141-144 (In Japanese).

OECD (1982): Eutrophication of Waters, p. 154.
OECD, Paris.

OHMori, T. and I. Ikushima (1988): Habitat and growth of aquatic macrophytes in Lake OzeNuma during ice-free season. Jpn. J. Limnol., 49: 279-285 (in Japanese with English summary).

Pratsinis, S. E., M. D. Zeldin and E. C. Ellis (1988) : Source resolution of the fine carbonaceous aerosol by principal component-stepwise regression analysis. Environ. Sci. Technol., 22 : 212-216.

Sakamoto, M. (1982): The chemical composition of pool waters on the Ozegahara moor and its ecological significance, p. 243-261. In H. HARA (ed.), Ozegahara, Scientific Researches of the Highmoor in Central Japan. Japan Society for the Promotion of Science, Tokyo.

SuGAWA, A. (1992) : Atsorption coefficient of yellow substance at the bottom in Lake Oze. Science Reports of the Faculty of Education, Gunma University, $40: 31-40$.

TezukA, Y. (1992) : Recent trend in the eutrophication of the north basin of Lake Biwa. Jpn. J. Limnol., 53 : 139-144.

UjiIye, A., Y. Hara, K. Yajima, A. Tanaka, M. KaneKo, A. Komatsubara and K. Kano (1981): Human influences in the eutrophication of Lake Oze-Numa. Water and Waste Water, $23: 1181$ 1189 (In Japanese).

VOLLENWEIDER, R. A. (1976): Advances in defining critical loading levels for phosphorus in lake eutrophication. Mem. Ist. Ital. Idrobiol., $33: 53$ -83 .

Yajima, K., M. Kaneko, A. Nagai, A. Tanaka, Y. HARA, K. Kano and A. UJIIYE (1983) : Nitrogen and phosphorus contents in the snow near the Oze district. Annual Report of Gunma Institute of Public Health, 15 : 133-140 (In Japanese).

Yajima, K., A. TANaka, Y. Kasal, A. Nagai, S. SEKI, Y. HARA and A. UJIIYE (1986) : Origin of COD in Lake Oze-Numa. Annual Report of Gunma Institute of Public Health, 18: 145-151 (In Japanese).

Yoshimi, H., K. OKA, K. IgUchi and H. SeKino (1982) : Water quality analysis of the Sagami River. Japan. J. Wat. Pollut. Res., 5 : 193-200 (In Japanese with English summary).

(著者：矢島久美子, 群馬県衛生環境研究所, $\mathbf{T} 371$ 群馬県前橋市岩神町3-21-19; Kumiko YAJMA, Gunma Prefectural Institute of Public Health and Environmental Sciences, 3-21-19 Iwagami-machi, Maebashi-shi 371) 
Received : 26 November 1995

Accepted : 15 April 1996 